Case Report

\title{
An extraskeletal osteosarcoma in the auricle of a Wistar Hannover rat
}

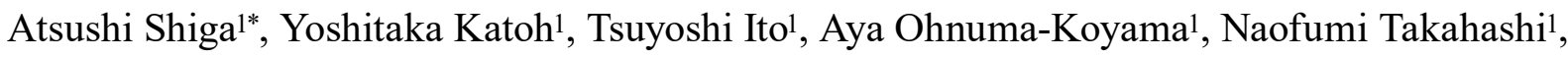 \\ Yoshimasa Okazaki¹, and Takanori Harada ${ }^{1}$
}

${ }^{1}$ The Institute of Environmental Toxicology, 4321 Uchimoriya-machi, Joso-shi, Ibaraki 303-0043, Japan

\begin{abstract}
An extraskeletal osteosarcoma was detected in the auricle of a 110-week-old female Wistar Hannover rat. Grossly, the tumor, measuring $15 \mathrm{~mm}$ in size, was observed in the subcutis as a solid and hard mass. Histologically, the majority of the mass comprised mature, compact bone. It was surrounded by neoplastic cells showing a variety of histologies, such as sarcoma, not otherwise specified, and myxosarcoma away from the bone-forming region. However, these different histological regions were considered to be components of a single bone tumor, based on the common expression of osterix and a similar mixture of constituent cells in each region. The tumor was diagnosed as an extraskeletal osteosarcoma because of the presence of infiltrative growth and abnormal mitosis and its development in the auricle without attachment to the skeleton. The present case is a rare histological type of an extraskeletal osteosarcoma with independent and different histological elements in rats. (DOI: 10.1293/tox.2018-0046; J Toxicol Pathol 2019; 32: 181-187)
\end{abstract}

Key words: rat, osteosarcoma, extraskeletal, auricle, osterix

Osteosarcoma (OS) is one of the most common malignant bone tumors in rats ${ }^{1}$. It occurs more frequently in males than in females $(4: 1)^{1}$. Most OSs in rats develop in the appendicular skeleton ${ }^{1}$. However, an OS may also arise at sites other than bone (soft tissue without attachment to the skeleton); this type of OS is known as an extraskeletal OS (ESOS). ESOSs in rats have been reported to originate in subcutaneous tissue, the spleen, and the digestive tract ${ }^{2}$.

A characteristic feature of OS is its histological diversity, which frequently manifests as a mixture of different histological patterns in the same tumor. Similarly, the cell morphology of OS varies, ranging from normal-appearing fibroblasts to bizarre, atypical cells. However, the most important histological feature of OS is the formation of bone or osteoid by the tumor cells ${ }^{1,2}$.

In the present study, we report the case of a rat auricular tumor considered to be an ESOS which exhibited cytological and histological diversity. Rat OSs are classified based on their histological appearance as simple, fibroblastic, osteoblastic, telangiectatic, and compound ${ }^{1}$. However, this OS did not match any of these histological types, and it was an extremely rare case which has never been reported.

The sample for the present case was obtained from a 110-week-old female Wistar Hannover (BrlHan:WIST@Jcl

Received: 11 September 2018, Accepted: 11 March 2019 Published online in J-STAGE: 15 April 2019

*Corresponding author: A Shiga (e-mail: shiga@iet.or.jp) (C2019 The Japanese Society of Toxicologic Pathology This is an open-access article distributed under the terms of the Creative Commons Attribution Non-Commercial No Derivatives (by-nc-nd) License. (CC-BY-NC-ND 4.0: https
creativecommons.org/licenses/by-nc-nd/4.0/).
[GALAS]) rat (CLEA Japan Inc., Shizuoka, Japan) that belonged to the treatment group of a two-year carcinogenicity study involving an agricultural chemical. The rat was housed in a wire-mesh stainless steel cage ( 2 rats/cage) in a barrier-sustained animal room under controlled conditions. The room's temperature and humidity were $22 \pm 2{ }^{\circ} \mathrm{C}$ and $50 \pm 20 \%$, respectively. It was ventilated 10 times or more per hour and illuminated for $12 \mathrm{~h}$ /day. The rat was fed a commercial diet (MF Mash, Oriental Yeast Co., Ltd., Tokyo, Japan) and tap water ad libitum. For environmental enrichment, paper sheets and a stainless-steel ring were put in the cage. The animal was handled during the study in accordance with the guidelines for animal experimentation issued by the Japanese Association for Laboratory Animal Science (JALAS) ${ }^{3}$ and with the Code of Ethics for Animal Experimentation of the Institute of Environmental Toxicology.

At week 65 of treatment, a mass measuring $5 \mathrm{~mm}$ in diameter was noted in the left auricle, which bore an ear tag. The rat did not show any clinical signs except for the auricular mass during the treatment period. At the time of scheduled sacrifice, the mass had increased to $15 \mathrm{~mm}$ in diameter. The mass was below the skin and hard. Besides the auriclar mass, a pituitary mass and splenic enlargement were observed as common age-related lesions. The auriclar mass was excised, fixed using 10\% neutral buffered formalin, and then decalcified in $10 \%$ formic acid. When the fixed mass was cut, it appeared homogeneous and solid, and the boundary between the mass and overlying skin was unclear. The mass was trimmed at three sites (I, II, and III) sagittally as indicated in Fig. 1a. The section surface of trimmed site I was the maximum cut surface (MCS) (Fig. 1b), and this surface was considered representative of the mass. The 

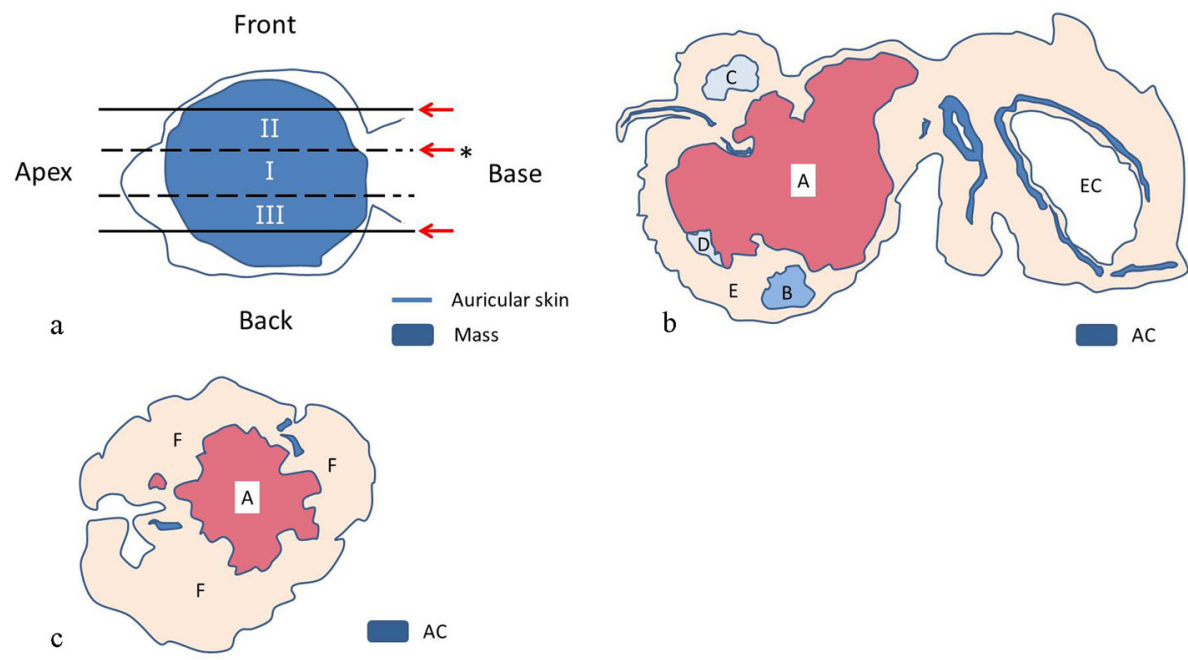

Fig. 1. (a) A schematic drawing showing the three trimmed sites (I, II, and III) of the auricular mass. Red arrows: section surface. Asterisk: maximum cut surface (MCS). (b) A schematic drawing showing the positional relationship among regions A to E in MCS of the auricular mass, derived from the section surface of trimmed site I (Fig. 1a). EC, ear canal; AC, auricular cartilage; region A, bone-forming; region $\mathrm{B}$, sarcoma, not otherwise specified; region C, myxosarcomatous; region D, myxomatous; and region E, regions other than regions A to D. (c) A schematic drawing of the positional relationship between regions A and F in cut surfaces other than the MCS of the auricular mass, derived from the section surface of trimmed site II (Fig. 1a). AC, auricular cartilage; region A, bone-forming; and region F, regions other than regions A.

trimmed masses were processed routinely and embedded in paraffin. The sections obtained from these three sites were stained with hematoxylin and eosin (H\&E). H\&Estained semi-serial sections were also acquired as needed. Additional sections were stained using Alcian Blue, AzanMallory, and toluidine blue stains, as well as the periodic acid-Schiff reaction to stain extracellular matrices. Sections were also immunostained with antibodies against mouse osterix (polyclonal, 1:200, Abcam, London, UK), mouse cytokeratin (clone: AE1/AE3, monoclonal, prediluted, Dako, Glostrup, Denmark), chicken desmin (polyclonal, prediluted, Dako), cow S-100 (polyclonal, 1:400, Dako), human $\alpha$-smooth muscle actin ( $\alpha$-SMA, clone: 1A4, monoclonal, 1:100, Dako), and rat macrophages (clone: ED-1, anti-CD8 antibody, monoclonal, 1:50, Serotec Ltd., Oxford, UK) for identification of cells, and rat proliferating cell nuclear antigen (PCNA, monoclonal, 1:200, Dako) for cell proliferation activity. For antigen retrieval, the sections were pre-treated with $0.4 \mathrm{mg} / \mathrm{mL}$ proteinase $\mathrm{K}$ (Dako) for macrophages (ED1) and heated at a temperature of $100^{\circ} \mathrm{C}$ for $10 \mathrm{~min}$ for PCNA analysis. EnVision+ System-HRP anti-rabbit or anti-mouse immunoglobulin G antibodies (Dako) were used as secondary antibodies. Sections stained without primary antibodies served as negative controls. Vascular smooth muscle in the tumor tissue stained for desmin and $\alpha$-SMA, epidermis in the tumor tissue stained for cytokeratin and PCNA, and control rat femur tissue stained for osterix, S-100, and ED-1 were used as positive control sections. Furthermore, paraffin-embedded sections from the femur of a young male rat ( 8 weeks old) of the same strain were used to compare the results obtained following histochemical staining of bone tissue specimens. The obtained sections were examined his- tologically using a light microscope.

The most characteristic histological finding in the present case was the different histological elements existing independently in different regions within the same mass. Histological and cytological features in regions $\mathrm{A}$ to $\mathrm{F}$ are summarized in Table 1, and schematic drawings of the positional relationship between regions $\mathrm{A}$ to $\mathrm{F}$ are presented in Fig. $1 \mathrm{~b}$ and $\mathrm{c}$. The mass consisted of the following regions: bone-forming (region A); sarcoma, not otherwise specified (region B), myxosarcomatous (region $\mathrm{C}$ ), and myxomatous (region D) regions and regions other than regions A to D (region E). Moreover, we defined the area surrounding region $\mathrm{A}$ in the sections from sites other than the MCS as region $\mathrm{F}$ (Fig. 1c: section surface of trimmed site II in Fig. 1a). Additionally, representative images of regions A to F are presented in Fig. 2a to f. Region A, which was composed of mature, compact bone trabeculae and was associated with many lacunae, comprised the majority of the mass (Fig. 2a and 3a).

In region $\mathrm{A}$, the nuclei of cells within the bone trabeculae were much smaller than those in the cells surrounding the trabeculae. Moreover, the cellularity was relatively high in the lacunae compared with the bone trabeculae. These cells were not aligned on the bone surface. Region A clearly expanded into the surrounding tissues in several areas (Fig. 3a). Semi-serial sections revealed the presence of focal necrosis, high cellularity areas, and many osteoclastlike cells (OCLs) in region A. In the high cellularity areas, the constituent cells exhibited slight nuclear pleomorphism with various amounts of chromatin. Furthermore, there were no significant differences in tinctorial properties of the trabecular bone matrix between the control rat femur and the tumorous bone, based on the results of examination with 
Table 1. Summary of Histopathological Features in Regions A to F

\begin{tabular}{|c|c|c|c|c|c|c|c|c|c|}
\hline \multirow{2}{*}{ Regions } & \multirow{2}{*}{$\begin{array}{c}\text { Positional } \\
\text { relationship } \\
\text { with region A }\end{array}$} & \multirow{2}{*}{$\begin{array}{c}\text { Biologic } \\
\text { behavior } \\
\text { of tumor cell }\end{array}$} & \multirow{2}{*}{$\begin{array}{l}\text { Histological } \\
\text { proliferation } \\
\text { pattern }\end{array}$} & \multicolumn{4}{|c|}{ Morphological features of tumor cell } & \multirow{2}{*}{$\begin{array}{c}\text { Bone/ } \\
\text { osteoid } \\
\text { formation }\end{array}$} & \multirow{2}{*}{ Stroma } \\
\hline & & & & Nucleus & Cytoplasm & $\begin{array}{c}\text { Nuclear } \\
\text { pleomorphism }\end{array}$ & $\begin{array}{l}\mathrm{N} / \mathrm{C} \\
\text { ratio }\end{array}$ & & \\
\hline A & NA & expansive & NA & $\begin{array}{l}\text { cigar to spindle, } \\
\text { hyperchromatic }\end{array}$ & scant & $\begin{array}{c} \pm \\
\text { (shape) }\end{array}$ & high & $\begin{array}{l}\text { bone } \\
(+++)\end{array}$ & bone \\
\hline B & away & infiltrative & fascicular & ovoid to spindle & $\begin{array}{l}\text { spindle, pale } \\
\text { basophilic }\end{array}$ & $\begin{array}{c}+ \\
\text { (shape \& size) }\end{array}$ & low & $\begin{array}{c}\text { osteoid } \\
( \pm)\end{array}$ & none \\
\hline $\mathrm{C}$ & away & infiltrative & none & spindle & $\begin{array}{l}\text { wavy spindle, } \\
\text { eosinophilic }\end{array}$ & $\begin{array}{c}+ \\
\text { (shape) }\end{array}$ & low & none & $\begin{array}{c}\text { edematous } \\
(++)\end{array}$ \\
\hline $\mathrm{D}$ & contact & none & none & $\begin{array}{l}\text { spindle to polygonal, } \\
\text { hyperchromatic }\end{array}$ & scant, stellate & $\begin{array}{c} \pm \\
\text { (shape) }\end{array}$ & high & none & $\begin{array}{c}\text { mucinous } \\
(+++)\end{array}$ \\
\hline $\mathrm{E}$ & contact & infiltrative & none & $\begin{array}{l}\text { ovoid to polygonal, } \\
\text { bizarre }\end{array}$ & $\begin{array}{c}\text { miscellaneous, } \\
\text { eosinophilic }\end{array}$ & $\begin{array}{c}+++ \\
\text { (shape \& size) }\end{array}$ & high & none & $\begin{array}{l}\text { edematous } \\
(+++)\end{array}$ \\
\hline $\mathrm{F}$ & contact & infiltrative & none & $\begin{array}{l}\text { ovoid, coarse } \\
\text { chromatin }\end{array}$ & $\begin{array}{c}\text { ovoid, } \\
\text { eosinophilic }\end{array}$ & $\begin{array}{c}+ \\
\text { (shape) }\end{array}$ & middle & $\begin{array}{l}\text { osteoid } \\
(+)\end{array}$ & $\begin{array}{l}\text { edematous to } \\
\text { collagenous } \\
\qquad(++)\end{array}$ \\
\hline
\end{tabular}

NA: not applicable, N/C ratio: nucleus-to-cytoplasm ratio. Gradings: \pm ; minimal, +; slight, ++; moderate, +++; marked

the special stains.

Osteoid formation was noted in regions B (Fig. 2b) and $\mathrm{F}$ (Fig. 3b), although it was rare. In regions $\mathrm{C}$ to $\mathrm{F}$, the stroma was either myxomatous or edematous in H\&E sections (Fig. 2c-f), but stroma that was positive for Alcian Blue was limited to region $\mathrm{D}$. In region $\mathrm{E}$, the constituent cells exhibited a variety of morphologies ranging from that of normal fibroblast-like cells to that of extremely atypical cells having bizarre, single, or multiple giant nuclei (Fig. 2e). Mitotic aberrations, such as multipolar division, were rarely observed. Histological examination of semi-serial sections from the MCS revealed that cells in regions $B$ to $D$ were intermingled with cells in region $\mathrm{E}$.

In region $\mathrm{F}$, the constituent cells coexisted with cells from region A (Fig. 3b and c) and exhibited the ability to form bone and osteoid tissues (Fig. 3b). Moreover, cells in region $\mathrm{F}$ were also observed in region $\mathrm{E}$, as demonstrated in semi-serial sections. Regions B, C, E, and F contained an infiltrative growth, and it was difficult to distinguish between their constituent cells and the fibroblasts in the dermis and subcutaneous tissues of the auricle, especially in regions $\mathrm{E}$ and $\mathrm{F}$. There were many mitotic cells in regions $\mathrm{B}, \mathrm{C}, \mathrm{E}$, and F, but none were observed in regions $\mathrm{A}$ and $\mathrm{D}$.

The auricular cartilage was divided into two portions (the distal and proximal) by region A (Fig. 1b). The proximal portion of the auricular cartilage showed degeneration, regenerative hyperplasia, and osseous metaplasia but was not connected to region A (Fig. 3d).

The immunostaining results are summarized in Table 2. The nuclei of cells in regions A to $\mathrm{F}$ were positive for osterix, although the positivity rate and staining intensity varied among regions. Region A was the region with the highest positive rate for osterix (Fig. 4a). With respect to regions $\mathrm{B}$ to $\mathrm{F}$, the highest positivity for osterix was detected in region $\mathrm{C}$ (Fig. 4b) and the osteoid-forming area in region F (Fig. 4c). However, nuclear positivity for osterix in cells in region $\mathrm{F}$ in close proximity to region $\mathrm{A}$ was not as strong (Fig. 4d) as that seen in region A. Interestingly, cells showing cytoplasmic positivity for osterix were frequently observed in regions $\mathrm{E}$ (Fig. 4e) and F, in hyperplastic chondrocytes in the regenerative area of the auricular cartilage (Fig. 4f), and in fibroblasts in the hyalinized dermis of the auricle, though osterix positivity was limited to the nucleus in other regions. Immunostaining with the other antibodies detected S-100 protein-positive tumor cells focally in region F (Fig. 4g). Furthermore, a few cytokeratin-positive tumor cells were located in region $\mathrm{A}$, whereas no desmin- or $\alpha$-SMA-positive tumor cells were present in any of the regions. OCLs in region A were positive for ED-1, but no ED1-positive cells were observed in other regions. The number of PCNA-positive cells was correlated with the number of mitotic cells and/or the severity of nuclear pleomorphism; that is, the PCNA positivity rate was high in regions $\mathrm{B}$ (Fig. 4h), C, E, and F and low in regions A and D (Table 1 and 2).

The most important diagnostic points in the present case were determining whether region A was tumorous or not and whether regions $\mathrm{B}$ to $\mathrm{F}$ were components of region A. The tissue in region A was considered to be tumor tissue and not metaplastic bone because of its expansive growth, high cellularity, the presence of many lacunae and the absence of hematopoietic or adipose tissue. Cells in region $\mathrm{F}$ were intermingled with those in region A. A similar group of cells was also located in region E. Moreover, the cells in regions $\mathrm{B}$ to $\mathrm{D}$ were intermingled with those in region E. Therefore, regions $\mathrm{A}$ to $\mathrm{F}$ were considered to be components of one osteogenic tumor tissue. The presence of a diffuse distribution of osterix-positive cells throughout regions A to F corroborated this finding. Furthermore, based on this immunostaining result, the present case should be differentiated from osteoma and osteoblastoma, which are compact bone-forming tumors. Additionally, the focal ne- 

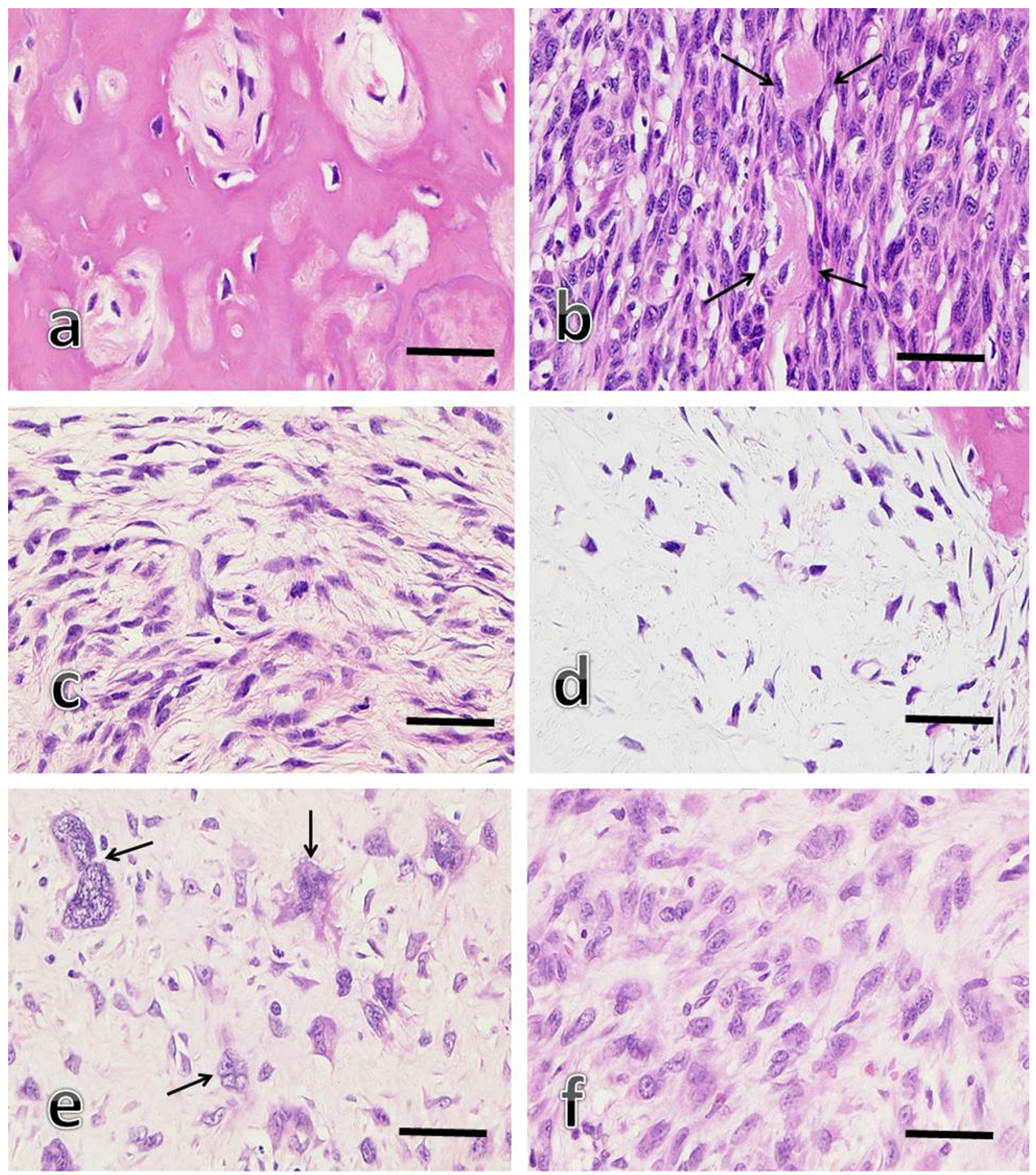

Fig. 2. Representative histological images of regions A to F. (a) Region A is composed of mature, compact bone trabeculae and contains many lacunae. Nuclear chromatin is abundant in constituent cells, and constituent cells show a high nucleus/cytoplasm ratio. (b) Region B is composed of atypical mesenchymal cells with osteoid formation (arrows) which have undergone fascicular proliferation. (c) Region C is composed of elongated fibroblast-like cells which exhibit nuclear pleomorphism. The stroma is edematous. (d) Region D is composed of small cells which exhibit nuclear pleomorphism. The stroma is abundant in the mucoid substance. (e) Region E is composed of pleomorphic large cells having bizarre nuclei (arrows). The stroma is edematous. (f) Region F is composed of large pleomorphic cells with abundant cytoplasm. H\&E stain. Scale bars $=50 \mu \mathrm{m}(\mathrm{a}-\mathrm{f})$.

crosis in region $\mathrm{A}$, the presence of sarcomatous areas showing obvious infiltrative growth, and the presence of abnormal mitotic figures in regions B, C, and/or E were indicative of the malignant characteristics of the tumor in the present case. Based on these findings, the tumor was considered to be malignant (i.e., OS), specifically an ESOS, because of its extraskeletal development.

The present ESOS is suspected to have developed in the metaplastic bone. Auricular chondropathy ${ }^{4}$ is an age-related lesion that has a high incidence rate in rats. Advanced cases are accompanied by significant metaplastic bone formation. However, the auricular chondropathy in the present case was less severe, and there was little metaplastic bone formation. Additionally, we recently identified an ESOS showing a histological type of a common OS in the auricle of a rat without auricular chondropathy and metaplastic bone (data not shown). Therefore, the ESOS in the present case was considered not to be associated with a metaplastic bone. On 

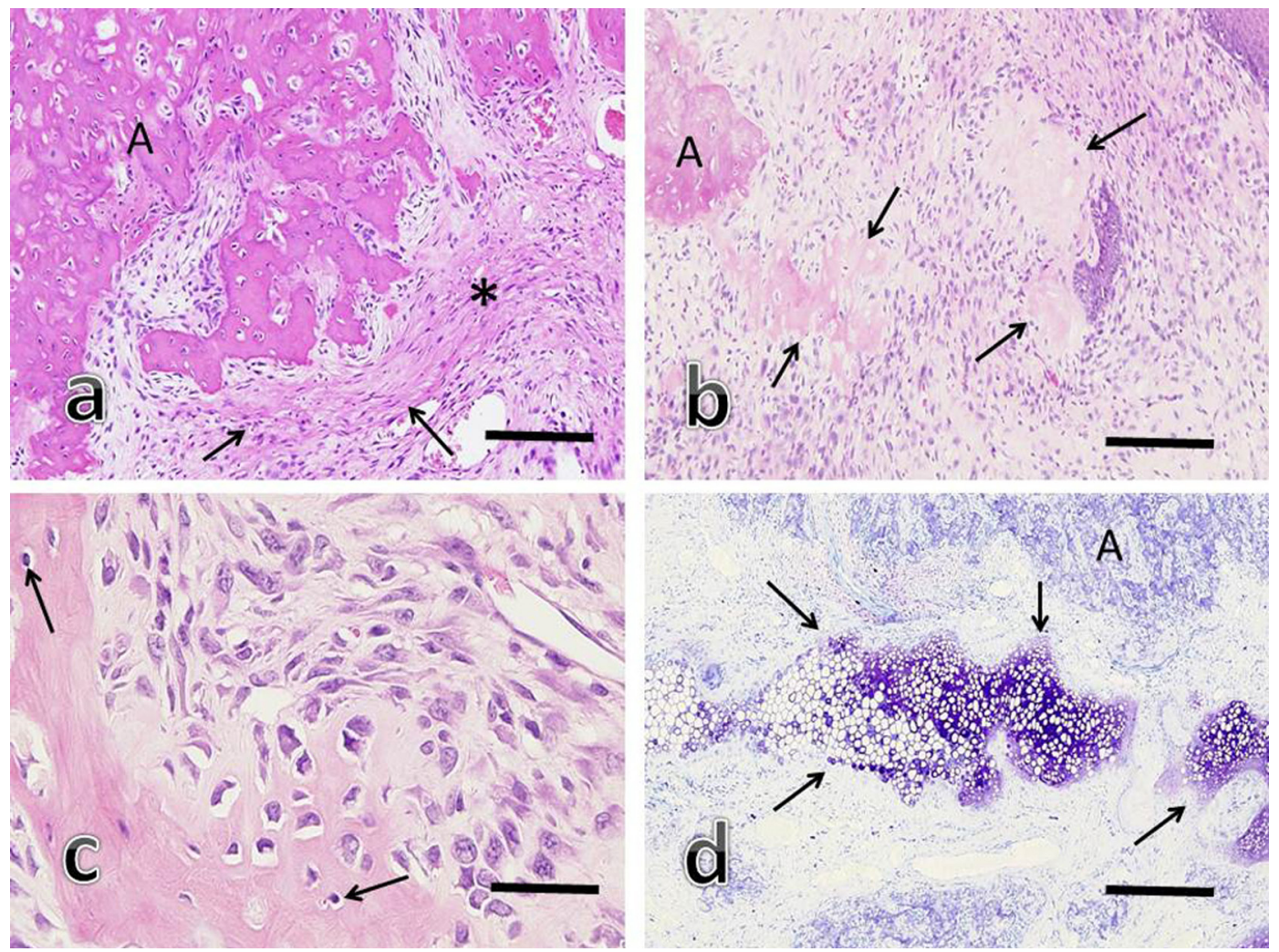

Fig. 3. Histological images showing diagnostic characteristics. (a) Region A (A) expands into the surrounding connective tissue (*) (arrows). (b) Tumor cells are abundant around osteoids (arrows) in region F but scarce around osteoids in region A (A). (c) Pleomorphic tumor cells in region F surround region A. Cells within bone trabeculae (arrows) are smaller than those surrounding bone trabeculae. (d) The proximal portion of the auricular cartilage (arrows). The thickness of the cartilage is irregular, but the cartilage is not connected to region A (A). H\&E stain (a-c) and toluidine blue stain (d). Scale bars $=400 \mu \mathrm{m}(\mathrm{a}, \mathrm{b}), 50 \mu \mathrm{m}$ (c), and $500 \mu \mathrm{m}(\mathrm{d})$.

Table 2. Summary of Immunohistochemical Results of Neoplastic Cells in Regions A to F

\begin{tabular}{|c|c|c|c|c|c|c|c|}
\hline \multirow{3}{*}{ Regions } & \multicolumn{7}{|c|}{ Immunohistochemical markers used } \\
\hline & \multicolumn{2}{|c|}{ Osterix } & \multirow{2}{*}{ S-100 } & \multirow{2}{*}{ Cytokeratin } & \multirow{2}{*}{$\alpha$-SMA } & \multirow{2}{*}{ Desmin } & \multirow{2}{*}{$\mathrm{PCNA}^{\mathrm{a})}$} \\
\hline & Nucleus & Cytoplasm & & & & & \\
\hline A & +++ & - & - & \pm & - & - & \pm \\
\hline B & \pm & - & - & - & - & - & +++ \\
\hline C & + & - & - & - & - & - & ++ \\
\hline $\mathrm{D}$ & + & - & - & - & - & - & + \\
\hline E & \pm & ++ & - & - & - & - & ++ \\
\hline $\mathrm{F}$ & + & ++ & + & - & - & - & ++ \\
\hline
\end{tabular}

Abbreviations: S-100; S-100 protein, $\alpha$-SMA; $\alpha$-smooth muscle actin, PCNA; proliferating cell nuclear antigen. Gradings; -: none, \pm : minimal, +: slight, ++: moderate, +++ : marked. a)positive rate.

the other hand, OS (ESOS) development secondary to inflammation as a result of ear tagging has been reported 5 . The ESOSs in both the present and the recently reported cases occurred in the auricle with an ear tag. Therefore, a causal relationship between OS (ESOS) development and ear tagging in the present case cannot be dismissed, although no obvious inflammation was observed. However, the ESOS presented in this report was considered to have developed spontaneously because of no relation to the effect of test substance treatment.
Osteocalcin and osteonectin are osteoblast markers, but the results obtained after immunohistochemistry for these markers are variable, especially for osteonectin ${ }^{6}$. These two markers may help to distinguish osteoids from dense collagen?. However, osteoid formation was extremely rare in the present case. Therefore, we used osterix as an osteoblast marker for the present case because of its expression in nuclei in areas other than bone matrix. Osterix, a transcription factor for osteoblast differentiation, serves as a differential marker for osteoblasts. The positive rate of os- 

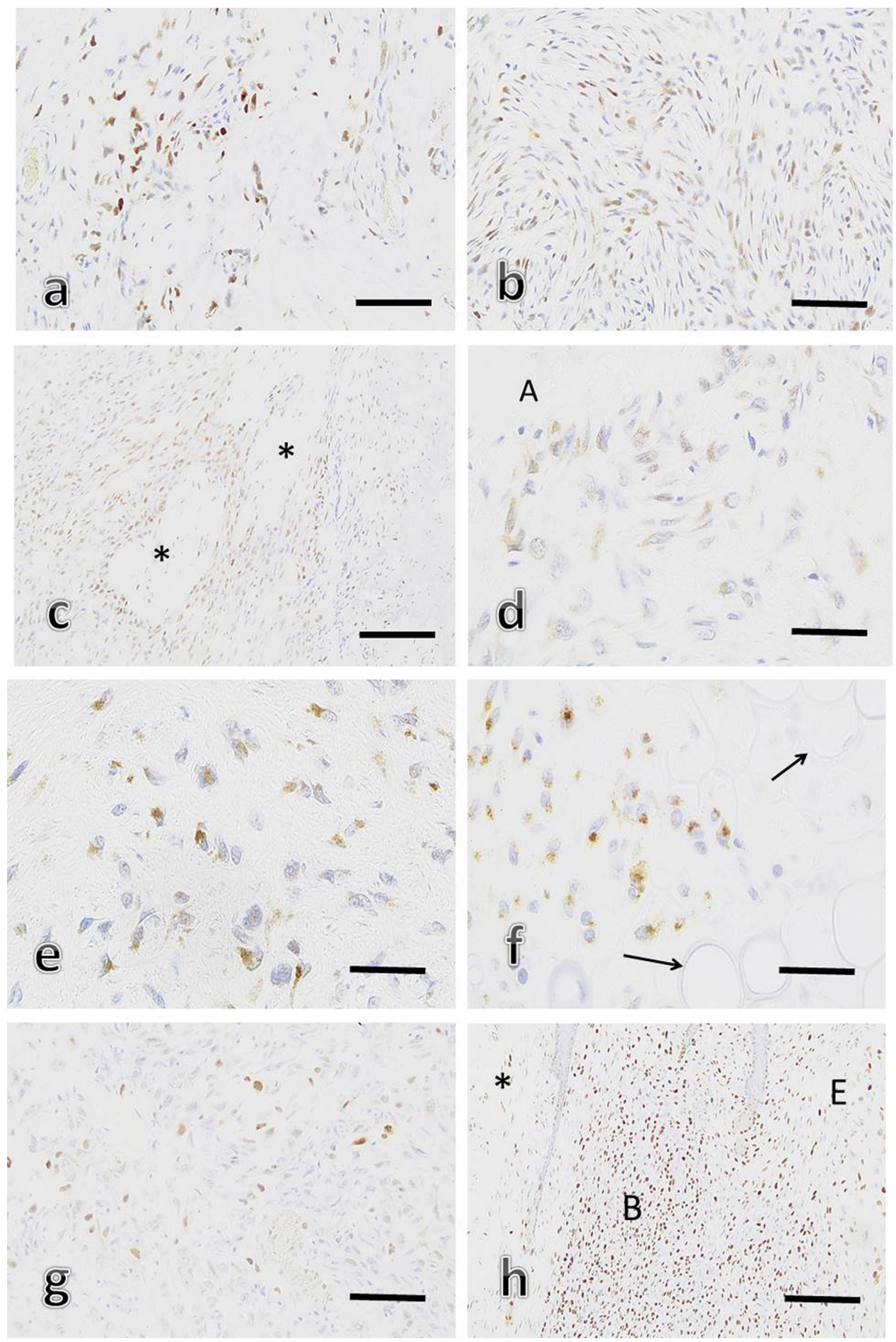

Fig. 4. Immunostaining with anti-osterix (a-f), anti-S-100 (g), and anti-proliferating cell nuclear antigen (PCNA) (h) antibodies. (a) Strong nuclear positivity for osterix in region A cells. (b) Area showing nuclear positivity for osterix in region $\mathrm{C}$ cells, but the intensity of the staining is weak compared with that in region A. (c) Cells surrounding osteoids $\left(^{*}\right)$ in region $\mathrm{F}$ show strong nuclear positivity for osterix. (d) Cells in region $\mathrm{F}$ which surround region $\mathrm{A}(\mathrm{A})$ are osterix positive in either the nucleus or cytoplasm, but the intensity of the staining is weak. (e) Cells in region E show cytoplasmic positivity for osterix. (f) Hyperplastic chondrocytes, but not normal chondrocytes (arrows), in the auricular cartilage show cytoplasmic positivity for osterix. (g) S-100 protein-positive cells in region F. (h) The highest number of PCNA-positive cells was observed in region B (B), followed by region E, and the lowest number of PCNA-positive cells was observed in fibroblasts in the hyalinized dermis $(*)$. Scale bars $=400 \mu \mathrm{m}(\mathrm{a}, \mathrm{b}, \mathrm{g}), 500 \mu \mathrm{m}(\mathrm{c}, \mathrm{h})$, and $50 \mu \mathrm{m}(\mathrm{d}-\mathrm{f})$. 
terix is inversely correlated with its biological behavior ${ }^{8}$. In fact, most cells in the bone-forming region (region $\mathrm{A}$ ) were positive for osterix, whereas fewer cells were positive for it in other regions.

Interestingly, cells showing cytoplasmic positivity for osterix were distributed in regions $\mathrm{E}$ and $\mathrm{F}$, as evidenced by the strong intensity and specificity observed after immunostaining. Similarly, human chondrogenic tumors also display this cytoplasmic positivity for osterix ${ }^{9}$. However, osterix is a nuclear transcription factor, and its immunoreactivity is limited to the nucleus in general ${ }^{10}$. Additionally, OS cells in humans are known to be immunopositive for cytokeratin, SMA, S-100, and epithelial membrane antigen ${ }^{11}$. Although rare, cytokeratin-positive cells were also observed in the present case in addition to S-100-positive cells. Unusual expression of these markers may also indicate the cytological diversity of OS. OS is considered to be a disease which results from the abnormal differentiation of osteoprogenitors $^{12}$, and the cytoplasmic positivity for osterix in the present case may be related to differentiation abnormalities. The results obtained after immunostaining support the diagnosis of OS (ESOS) in the present case.

Diagnosis of common OS in rats is usually easy because of the obvious osteoid formation by anaplastic mesenchymal tumor cells ${ }^{1}$. However, the difficulty associated with making a diagnosis in the present case had to do with determining whether the tumor cells produced osteoid and/ or bone because the malignant neoplastic cell foci (in regions $\mathrm{B}$ and $\mathrm{C}$ ) which showed infiltrative growth were located distant from the bone-forming area (region A). Also, the histological diversity of OS suggests that there are transitional areas between different regions. However, in the present case, each histological region was well demarcated and isolated from other regions. Therefore, the interpretation of the relationships between region $\mathrm{A}$ and regions $\mathrm{B}$ to F contributed significantly to the diagnosis of the ESOS in the present case.

For a definitive diagnosis of OS, trimming tissue from multiple sites has been recommended because of the histological diversity of OS6. The present case does demonstrate the importance of this technique and the necessity of use of serial sections. The present case is a rare histological type of an extraskeletal osteosarcoma with independent and different histological elements in rats, although auricular OSs in rats have already been reported in a textbook ${ }^{13}$.

Disclosure of Potential Conflicts of Interest: The authors declared no potential conflicts of interest with respect to the research, authorship, and/or publication of this article.

Acknowledgments: We thank Mrs. Chizuko Tomiyama for her assistance in tissue preparation.

\section{References}

1. Fossey SL, Vahle JL, and Leininger JR. Bones, Joints and Synovia. In: Boorman's Pathology of the Rat. Reference and Atlas, 2nd ed. AW Suttie (ed). Academic Press, San Diego. 299-322. 2018.

2. Fossey S, Vahle J, Long P, Schelling S, Ernst H, Boyce RW, Jolette J, Bolon B, Bendele A, Rinke M, Healy L, High W, Roth DR, Boyle M, and Leininger J. Nonproliferative and proliferative lesions of the rat and mouse skeletal tissues (bones, joints, and teeth). J Toxicol Pathol. 29(Suppl): 49S103S. 2016. [Medline] [CrossRef]

3. Japanese Association for Laboratory Animal Science. Guidelines for animal experimentation. Exp Anim. 36: 285-288. 1987.

4. Chiu T, and Lee KP. Auricular chondropathy in aging rats. Vet Pathol. 21: 500-504. 1984. [Medline] [CrossRef]

5. Waalkes MP, Rehm S, Kasprzak KS, and Issaq HJ. Inflammatory, proliferative, and neoplastic lesions at the site of metallic identification ear tags in Wistar [Crl:(WI)BR] rats. Cancer Res. 47: 2445-2450. 1987. [Medline]

6. Thompson KG, and Dittmer KE. Tumors of Bone. In: Tumors in Domestic Animals. 5th ed. DJ Meuten (ed). John Wiley \& Sons, Inc., Ames. 356-424. 2017.

7. Fanburg-Smith JC, Bratthauer GL, and Miettinen M. Osteocalcin and osteonectin immunoreactivity in extraskeletal osteosarcoma: a study of 28 cases. Hum Pathol. 30: 32-38. 1999. [Medline] [CrossRef]

8. Cao Y, Zhou Z, de Crombrugghe B, Nakashima K, Guan H, Duan X, Jia S-F, and Kleinerman ES. Osterix, a transcription factor for osteoblast differentiation, mediates antitumor activity in murine osteosarcoma. Cancer Res. 65: 1124-1128. 2005. [Medline] [CrossRef]

9. Dancer JY, Henry SP, Bondaruk J, Lee S, Ayala AG, de Crombrugghe B, and Czerniak B. Expression of master regulatory genes controlling skeletal development in benign cartilage and bone forming tumors. Hum Pathol. 41: 1788-1793. 2010. [Medline] [CrossRef]

10. Nakashima K, Zhou X, Kunkel G, Zhang Z, Deng JM, Behringer RR, and de Crombrugghe $\mathrm{B}$. The novel zinc fingercontaining transcription factor osterix is required for osteoblast differentiation and bone formation. Cell. 108: 17-29. 2002. [Medline] [CrossRef]

11. Raymond AK, Ayala AG, and Mnuutila S. Conventional osteosarcoma. In: WHO Classification of Tumours of Soft Tissue and Bone. 3rd ed. CDM Fletcher, KK Unni, and F Mertens (eds). International Agency for Research on Cancer. IARC Press. Lyon. 259-286. 2002.

12. Luo X, Chen J, Song W-X, Tang N, Luo J, Deng Z-L, Sharff KA, He G, Bi Y, He B-C, Bennett E, Huang J, Kang Q, Jiang W, Su Y, Zhu G-H, Yin H, He Y, Wang Y, Souris JS, Chen L, Zuo G-W, Montag AG, Reid RR, Haydon RC, Luu $\mathrm{HH}$, and $\mathrm{He} \mathrm{T}-\mathrm{C}$. Osteogenic BMPs promote tumor growth of human osteosarcomas that harbor differentiation defects. Lab Invest. 88: 1264-1277. 2008. [Medline] [CrossRef]

13. Yoshitomi K, and Brown HR. Ear and pinna. In: Boorman's Pathology of the Rat. Reference and Atlas, 2nd ed. AW Suttie (ed). Academic Press, San Diego. 241-251. 2018. 